\title{
血小板凝集におよぼす顆粒球エラスターゼの影響
}

\author{
滝 正志* 稲垣 稔* 富田 幸治* 三浦 琢磨* \\ 斉藤 伸夫* 上田 康信** 目黒 嵩*** 山田 兼雄***
}

\section{Influence of granulocyte elastase-like proteinase (ELP) on platelet aggregation}

\author{
Masashi TAKI*, Minoru INAGAKI*, Yukiharu TOMITA*, \\ Takuma MIURA*, Nobuo SAITO*, Yasunobu UEDA**, \\ Takashi MEGURO* and Kaneo YAMADA*
}

\author{
Key words: granulocyte elastase-like proteinase (ELP), \\ platelet aggregation, thromboxane $\mathrm{A}_{2}$
}

The influence of granulocyte elastase-like proteinse (ELP) on platelet aggregation was investigated by using the method in which agonist such as ADP, epinephrine, thrombin, collagen, arachidonic acid, A 23187 or ristocetin, cofactor such as fibrinogen or von Willebrand factor, or the suspended platelets in calcium free Hepes Tyrode albumin buffer was respectively incubated with ELP.

ELP treatment of agonists except collagen or thrombin resulted in no change of the ability to induce aggregation. On the other hand, the treated collagen showed the decrease of the ability, however, the treated thrombin showed the slight increase of the ability. ELP treatment of cofactor such as fibrinogen or vWF resulted in the decrease of the cofactor activity corresponding to the change of its molecular form. Platelet aggregation in ELP treated platelets was markedly decreased by agonist such as thrombin, collagen, epinephrine or ristocetin, while it was not as greatly decreased by arachidonic acid, ADP or A 23187.

These results demonstrated that the influence of ELP on platelet aggregation was mainly caused by direct inactivation of platelets. ELP also acted on cofactor such as fibrinogen or vWF and a part of agonist such as collagen or thrombin, and subsequently influenced upon the aggregation.

\footnotetext{
* 慶応義塾大学医学部小児科 [₹160 東京都新宿区信濃町 35], Department of Pediatrics, Keio University School of Medicine, Tokyo, Japan.

** 荻窪病院中検血液, Research Project of Haematology, Ogikubo Hospital, Tokyo, Japan.

*** 聖マリアンナ医科大学小児科, Department of Pediatrice, St. Marianna University, School of Medicine, Kanagawa, Japan.
} 


\section{目的}

顆粒球エラスターゼ (ELP) はエラスチン分 解のみならず凝固線溶因子に種々の影響を与え ることが知られている ${ }^{1 \sim 3)}$. 今回の ELP 血小板 凝集に与える影響について基礎的な検討を行な った.

\section{I. 材料および方法}

ELP : 永松等の方法 $\left.{ }^{4}{ }^{5}\right)$ に従いクエン酸加全 血より精製した。血小板凝集・放出: Hepes Tyrode Albumin 溶液で洗浄した血小板浮遊液 (WP) を用いて比濁法による凝集を観察した。 $\mathrm{TXA}_{2}$ 放出は山崎等の方法 ${ }^{6)}$ ，すなわち WP agonist を作用させ 5 分後の medium に放出さ れる $\mathrm{TXA}_{2}$ を RIA で $\mathrm{TXB}_{2}$ として測定した. ELP の作用 : agonist (ADP, epinephrine, thrombin, collagen, arachidonic acid, A 23187, ristocetin), cofactor (fibrinogen, vWF), 血小 板 (WP) それぞれに $1 / 10$ 容の ELP を経時的 ならびに濃度別に作用させ血小板凝集を行なっ た.

\section{II. 成 績}

得られた ELP は $7 \%$ SDS-PAGE で single band で分子量約 3 万あった. な拈 ELP の単 位は $\mu \mathrm{mol} / \mathrm{min}$ の ATLV の amidolytic activityを $1 \mathrm{U}$ とした.

a) agonist に対する影響:ADP, epinephrine, アラキドン酸，A 23187，リストセチンに対す る影響は認められなかったが， collagen に対し ては凝集若起能の低下が観察された。一方， thrombin に対しては増強が観察され，この際 thrombin 時間の短縮としても認められた。

b ) cofactor に対する影響 : ELP 処理 fibrinogen の cofactor 活性は ELP の濃度，作用時間 に関連して低下した. この際凝固時間の延長, $5 \%$ SDS-PAGE 所見の僅かな分子量の減少 (非還元系)， $\alpha ， \beta ， \gamma$ 鎖の順で減少そして消 失 (還元系) する変化としても認められた. ELP 処理 vWF の cofactor 活性も同様に低下 しこの際抗原の見かけ上の増加も認められた.

c）血小板に対する影響：血小板の凝集の強
Table 1 Platelet aggregations in ELP treated platelets by various agonists

\begin{tabular}{l|c|c|c}
\hline \multirow{2}{*}{\multicolumn{1}{c|}{ Agonists }} & \multicolumn{2}{|c|}{ Aggregation (\%) } & \multirow{2}{*}{$\begin{array}{c}\text { Inacti- } \\
\text { vation } \\
(\%)\end{array}$} \\
\cline { 2 - 3 } & ELP & Buffer & $(\%)$ \\
\hline ADP+Fg & $37^{*}$ & $79^{*}$ & 53 \\
Epinephrine+Fg & 10 & 70 & 85 \\
Thrombin & 16 & 86 & 81 \\
Collagen & 1 & 30 & 97 \\
Arachidonic Acid & 49 & 65 & 26 \\
A 23187 & 60 & 65 & 7 \\
Ristocetin +vWF & 1 & 71 & 98 \\
\hline
\end{tabular}

ADP $(2 \mu \mathrm{M})$, Epinephrine $(50 \mu \mathrm{M})$, Thrombin ( 0 . $05 \mathrm{U} / \mathrm{ml})$, Collagen $(5 \mu \mathrm{g} / \mathrm{ml})$, Arachidonic acid $(50 \mu \mathrm{M})$, A $23187(5 \mu \mathrm{M})$, Ristocetin $(1.2 \mathrm{mg} / \mathrm{ml})$, $\mathrm{Fg}(0.1 \mathrm{mg} / \mathrm{m} l)$, vWF $(0.1 \mathrm{U} / \mathrm{ml})$.

Aggregation : maximum light transmission during 5 min.

Platelets were incubated with $\operatorname{ELP}(0.016 \mathrm{U} / \mathrm{ml})$ for $30 \mathrm{~min}(* 10 \mathrm{~min})$ at $37^{\circ} \mathrm{C}$ before the addition of agonists.
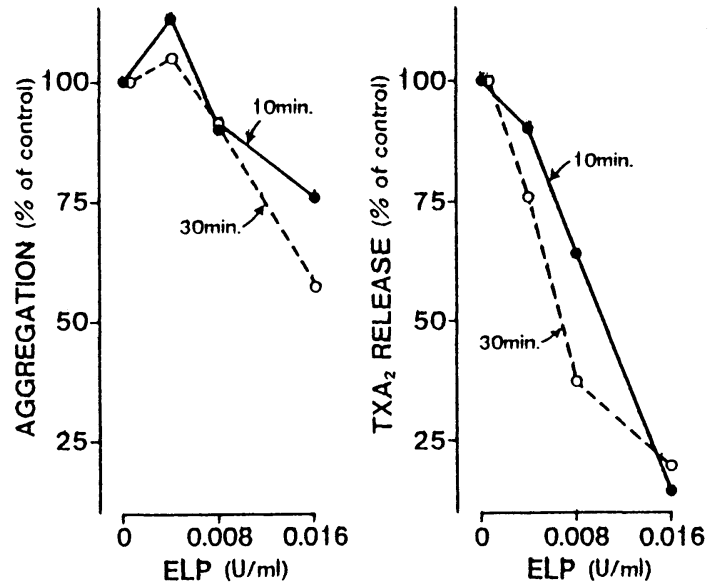

Fig. 1 Platelet aggregation and thromboxane $A_{2}$ $\left(\mathrm{TXA}_{2}\right)$ release in ELP treated platelets by thrombin $(0.1 \mathrm{U} / \mathrm{ml})$

10 min.: ELP treatment of platelets for $10 \mathrm{~min}$. at $37^{\circ} \mathrm{C}$

30 min.: ELP treatment of platelets for $30 \mathrm{~min}$. at $37^{\circ} \mathrm{C}$

さは thrombin, collagen, epinephrine, ristocetin で著しい低下，ADP，アラキドン酸で中等度の 低下，A23187 で軽度の低下が ELP の濃度， 作用時間に関連して観察された（表 1 ). TXA の放出は thrombin 凝集で ELP の濃度，作用 時間に関連して放出の著しい低下が認められた が(図 1 )，アラキドン酸凝集では全く低下が認 められずむしろ control よりも強い放出が認め 
られた。

\section{III. 考按}

ELP は一部の agonist, cofactor そして血小 板に作用して血小板凝集に強い影響を与えるこ とが認められた．特に血小板に対して内因性の アラキドン酸代謝を活性化する thrombin, collagen 等の凝集が強く抑制されるのに対し， ア ラキドン酸凝集が比較的軽度の抑制であった。 また $\mathrm{TXA}_{2}$ の放出が thrombin 誘発で強い抑 制が認められアラキドン酸誘発で全く抑制が認 められなかった，以上のことより ELP は直接 血小板膜に対して変化を与光，アラキドン酸よ り上位のレベルのアラキドン酸代謝を含めた初 期血小板活性化を抑制する可能性が強く示唆さ れた。

\section{文献}

1) Schmidt, W., Egbring, R. and Havemann, K.: Effect of elastase-like and chymotrypsin-like neutral proteases from human granulocytes on isolated clotting factors. Thromb. Res., 6; 315 326, 1975.

2) Kopec.M., Bykowska,K.,Lopaciuk, S., Jelenska, M., Kaczanowska, J., Sopata I. and Wojtecka,
E. : Effects of neutral proteases from human leukocytes on structure and biological properties of human factor VIII. Thromb. Haemostas., 43(3); 211 217, 1980.

3）三浦㙇磨，稲垣 稔，滝 正志，富田幸治，斎 藤伸夫, 目黒 嵩, 山田兼雄, 岡田芳男, 津田 裕子: 顆粒球 elastase (ELP) の血中存在様式. 炎症, 4；419 420, 1984.

4) Okada, Y., Tsuda, Y., Nagamatsu, Y. and Okamoto, U.: Convenient purification of human spleen fibrinolytic proteinase (SFP) and human leucocyte elastase by affinity chromatography. Chem. Pharm. Bull., 30; 1528 1530, 1982.

5) Nagamatsu, Y., Okamoto, U., Tsuda, Y. and Okada, Y.: Human leukocyte elastase-like proteinase purified by affinity chromatography with Suc-L-Tyr-D-Leu-D-Val-pNA, and its identification with human spleen fibrinolytic proteinase. Thromb. Haemostas., 51(2); 243 $\sim 247,1984$.

6）山崎博男，田上憲次郎，山口 敦美，榊原千枝 子, 山本正雅, 宗像純司, 川越 栄, 福田 純, 高野照夫，早川弘一：虚血性心疾患に扣ける 血小板トロボキサン $\mathrm{A}_{2}$ 合成能. 血液と脈管, 14(3); 354 356, 1983.

\section{○日常診療の落し穴と安全性を示す! \\ 小児の医療事故と救急処置}

編集 日本大学小児科教授 馬場一雄 専門医50氏分担執筆

B 5 判 337頁 図52 表120 定価9,800円(干350円)

巴101 東京都千代田区神田多町 2-11 